\title{
DYFUZOR ZAKRZYWIONY (O KONTROLOWANYM ZARYSIE)
}

\begin{abstract}
Zastosowanie sprężarek promieniowych i osiowo-promieniowych w silnikach śmigłowych, śmigłowcowych i dwuprzepływowych może wymagać konstrukcji małych średnic dyfuzora w celu uzyskania niższej masy i mniejszej powierzchni czołowej. Konwencjonalne dyfuzory wylotowe cechują duże średnice w przekroju wyjściowym dla wartości liczb Macha mniejszych od 0,2 oraz niskich zawirowań strumienia w komorze spalania, stąd konstrukcja kanału przepływowego dyfuzorów wylotowych o małych średnicach, zwanych dyfuzorami o kontrolowanym zarysie lub dyfuzorami zakrzywionymi, jest złożona. Zarys przekroju poprzecznego kanału przepływowego takiego dyfuzora zmienia się od okrągłego przez owalny na eliptyczny, a następnie prostokątny z dwoma promieniami bocznych zaokrągleń. W pracy przedstawiono oryginalną metodę wyznaczania parametrów strumienia w kanale oraz w przekroju wyjściowym dyfuzora zakrzywionego, stanowiącego układ wylotowy sprężarki promieniowej lub osiowo-promieniowej z dyfuzorem rurkowym. Zaprezentowano także nową metodę określenia parametrów geometrycznych tego dyfuzora. Wymienione metody mogą być stosowane w trakcie realizacji projektu koncepcyjnego sprężarki z wykorzystaniem twierdzenia Pitagorasa, właściwości elipsy, równania ciągłości, równania zachowania energii, pierwszej zasady termodynamiki, równania momentu ilości ruchu Eulera, funkcji gazodynamicznych oraz definicji stosowanych w teorii maszyn wirnikowych. Przedstawiono także zasady doboru obliczeniowej wartości sprężu sprężarki z dyfuzorem rurkowym.
\end{abstract}

Słowa kluczowe: sprężarka, układ wylotowy, dyfuzor zakrzywiony

\section{Wprowadzenie}

Dyfuzor zakrzywiony (rys. 1.) jest klasycznym, a zarazem jedynym rozwiązaniem konstrukcyjnym układu wylotowego sprężarki promieniowej z dyfuzorem rurkowym, a ich liczba jest równa liczbie kanałów tego dyfuzora. Za częścią stożkową wszystkich kanałów przepływowych dyfuzora rurkowego konstrukcja kadłuba tego dyfuzora zawiera gniazda mocowania dyfuzorów zakrzywionych (rys. 2.). Na rysunku 2. oznaczono także pomocniczy lewoskrętny układ współrzędnych o osiach $X 1, Y 1, Z 1$.

\footnotetext{
${ }^{1}$ Autor do korespondencji/corresponding author: Stanisław Antas, Politechnika Rzeszowska, al. Powstańców Warszawy 8, tel. (17) 8651501, e-mail: santas@ prz.edu.pl
} 
a)

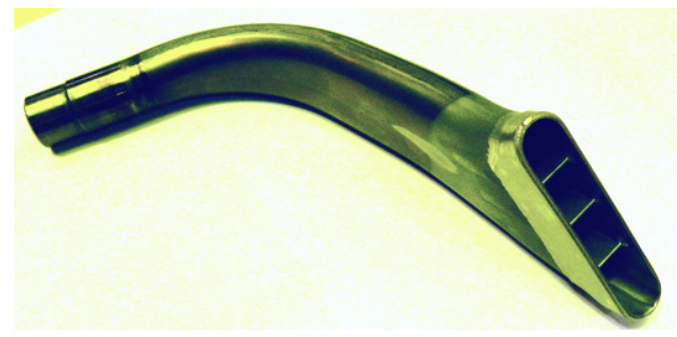

b)

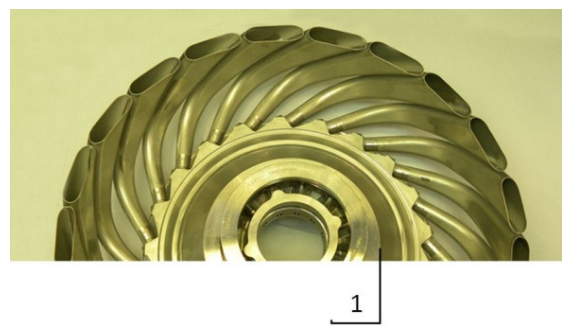

Rys. 1. Widok pojedynczego dyfuzora zakrzywionego (a) oraz zespołu dyfuzorów zakrzywionych (b): 1 - kadłub dyfuzora rurkowego (dzięki uprzejmości firmy Pratt and Whitney - dar dla Politechniki Rzeszowskiej)

Fig. 1. View of a single controlled-contour diffuser (a) and controlled-contour diffuser assembly (b): 1 - body of the pipe diffuser (a gift from Pratt and Whitney Company to the Rzeszow University of Technology)

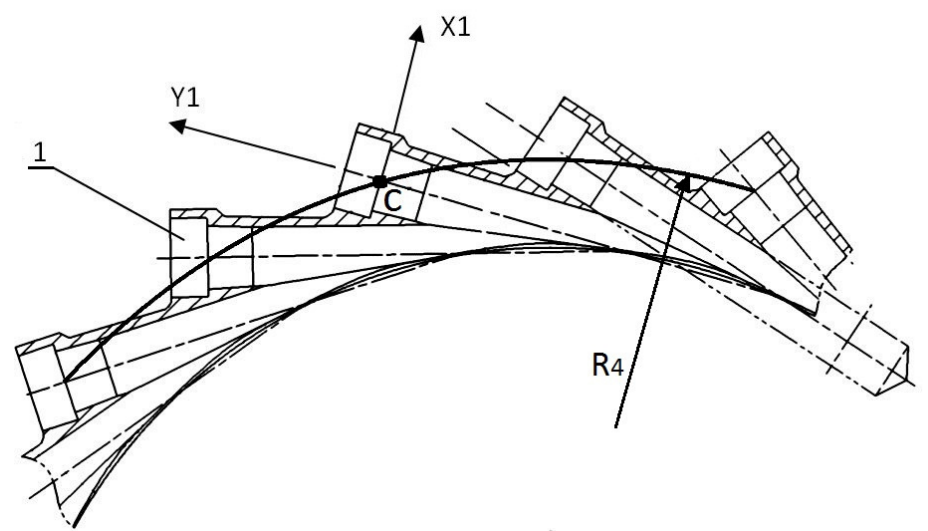

Rys. 2. Przekrój poprzeczny dyfuzora rurkowego: 1 - gniazdo mocowania dyfuzora zagiętego

Fig. 2. Cross section of a pipe diffuser: 1 - mounting pad for the controlled-contour diffuser

Oś dyfuzora zakrzywionego leży w płaszczyźnie wyznaczonej przez osie $Y 1$ i $Z 1$, przy czym oś $Z 1$ przechodzi przez punkt $C$ leżący na promieniu $R_{4}$ dyfuzora rurkowego i jest prostopadła do płaszczyzny rysunku. Dyfuzor zakrzywiony przedstawiony na rys. 3. jest wykonywany z blachy ze stali nierdzewnej przez tłoczenie dwóch połówek (górnej i dolnej), które następnie są wzdłużnie łączone lutowaniem. Część wlotowa ma kształt cylindra o średnicy wewnętrznej $d_{4}$ dyfuzora stożkowego, a w celu usztywnienia jest lutowana do tulei wlotowej dyfuzora zakrzywionego. Tuleja dyfuzora zakrzywionego, środkowana w gnieździe mocowania znajdującego się w kadłubie dyfuzora rurkowego, jest lutowana 
do tego kadłuba lub zawiera dodatkowo kołnierz mocowany do kadłuba za pomocą śrub [1].

a)

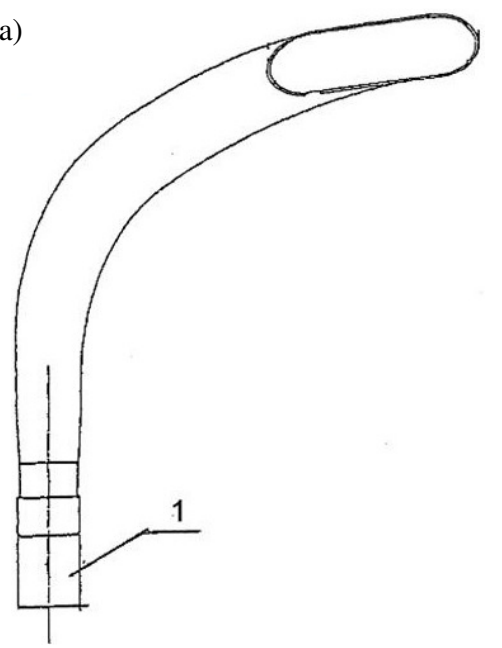

b)

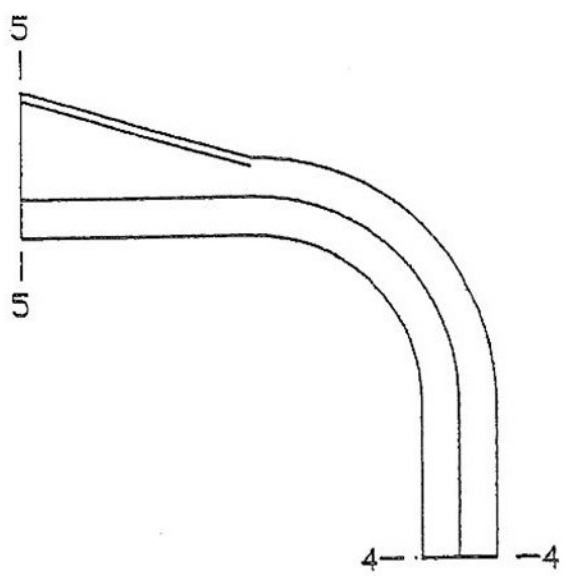

Rys. 3. Kanał przepływowy (a) i schemat (b) dyfuzora zakrzywionego z oznaczeniem charakterystycznych przekrojów: 1 - tuleja wlotowa

Fig. 3. Flow passage (a) and scheme (b) of the controlled-contour diffuser with markings of the characteristic sections: 1 - inlet sleeve

\section{Parametry strumienia na wylocie dyfuzora}

Parametry powietrza w przekroju wyjściowym (5-5) dyfuzora zakrzywionego (wlotowym komory spalania) można wyznaczyć w następującej kolejności.

Praca sił tarcia w dyfuzorze zakrzywionym:

$$
l r_{4,5}=\xi_{4,5} \frac{C_{4}^{2}}{2}
$$

gdzie współczynnik strat przepływu w dyfuzorze zakrzywionym $\xi_{4,5} \approx 0,19$ [1].

Prędkość krytyczna dźwięku w przekroju wyjściowym:

$$
a_{k r 5}=a_{k r 4}=\sqrt{\frac{2 k R}{k+1} T_{4}^{*}}
$$

gdzie wartość temperatury spiętrzenia na wlocie $T_{4}{ }^{*}$ jest znana $\mathrm{z}$ obliczeń projektowych dyfuzora rurkowego.

Prędkość strumienia w przekroju wyjściowym:

$$
C_{5}=\lambda_{5} a_{k r 5}
$$


gdzie wartość liczby Lavala prędkości bezwzględnej strumienia w przekroju wejściowym komory spalania wybiera się z zakresu $\lambda_{5}=0,11 \div 0,22$ [1].

Temperatura statyczna strumienia w przekroju (5-5):

$$
T_{5}=T_{4}{ }^{*}-\frac{C_{5}^{2}}{2 \frac{k R}{k-1}}
$$

lub

$$
T_{5}=T_{4}+\frac{C_{4}{ }^{2}-C_{5}{ }^{2}}{2 \frac{k R}{k-1}}
$$

Wykładnik politropy sprężania w dyfuzorze zakrzywionym wyznacza się z pierwszej zasady termodynamiki:

$$
\frac{n_{4,5}}{n_{4,5-1}}=\frac{k}{k-1}-\frac{l r_{4,5}}{R\left(T_{5}-T_{4}\right)}
$$

Oznaczając prawą stronę równania (6) przez

$$
E=\frac{k}{k-1}-\frac{l r_{4,5}}{R\left(T_{5}-T_{4}\right)}
$$

wartość wykładnika politropy $n_{4,5}$ określa równanie:

$$
n_{4,5}=\frac{E}{E-1}
$$

Ciśnienie statyczne strumienia w przekroju wyjściowym wyznacza równanie politropy:

$$
p_{5}=p_{4}\left(\frac{T_{5}}{T_{4}}\right)^{\frac{n_{4,5}}{n_{4,5}-1}}
$$

Względna gęstość strumienia masy powietrza w przekroju wyjściowym [2]:

$$
q\left(\lambda_{5}\right)=\lambda_{5}\left(1-\frac{k-1}{k+1} \lambda_{5}^{2}\right)^{\frac{1}{k-1}}\left(\frac{k+1}{2}\right)^{\frac{1}{k-1}}
$$

Funkcja gazodynamiczna temperatury:

$$
\tau\left(\lambda_{5}\right)=1-\frac{k-1}{k+1} \lambda_{5}^{2}
$$

Funkcja gazodynamiczna ciśnienia:

$$
\pi\left(\lambda_{5}\right)=\left(1-\frac{k-1}{k+1} \lambda_{5}^{2}\right)^{\frac{k}{k-1}}
$$


Temperatura spiętrzenia strumienia w przekroju wyjściowym:

$$
T_{5}^{*}=\frac{T_{5}}{\tau\left(\lambda_{5}\right)}
$$

Powinna być spełniona relacja $T_{5}{ }^{*}=T_{4}{ }^{*}$.

Ciśnienie spiętrzenia strumienia w przekroju (5-5):

$$
p_{5}^{*}=\frac{p_{5}}{\pi\left(\lambda_{5}\right)}
$$

Stopień strat ciśnienia spiętrzenia w dyfuzorze zakrzywionym:

$$
\sigma_{4,5}=1-\left(\frac{k}{k+1}\right) \xi_{4,5}\left(1-\frac{k-1}{k+1} \lambda_{4}^{2}\right)^{\frac{1}{k-1}} \lambda_{4}^{2}
$$

Sprawdzenie dokładności wyznaczenia wartości ciśnienia spiętrzenia strumienia w przekroju wyjściowym:

$$
p_{5}{ }^{*}=\sigma_{4,5} p_{4}{ }^{*}
$$

Obliczona wartość ciśnienia $p_{5}{ }^{*}$ powinna być równa wartości ciśnienia spiętrzenia określonej ze wzoru (14). locie:

Pole powierzchni pojedynczego kanału dyfuzora zakrzywionego na wy-

$$
F_{5,1}=\frac{\dot{\mathrm{m}} \sqrt{T_{5}{ }^{*}}}{Z_{D r} s p_{5}{ }^{*} q\left(\lambda_{5}\right) \sin \alpha_{5} K_{m}}
$$

gdzie kąt wypływu z dyfuzora zakrzywionego $\alpha_{5}=\operatorname{arctg} \frac{C_{5} a}{C_{5} u}$ powinien zawierać się w granicach $\alpha_{5}=75 \div 90^{\circ}$, natomiast $K_{m}=0,97 \div 0,98$ [3]. Jeżeli $\alpha_{5}<75^{\circ}$, na wylocie dyfuzora zakrzywionego stosuje się prostownice strumienia (rys.1a) o wydłużeniu topatek $\overline{h_{5}}=h_{5} / b=0,4 \div 0,5$.

Sumaryczne pole powierzchni dyfuzora zakrzywionego w przekroju wyjściowym:

$$
F_{5}=Z_{D r} F_{5,1}
$$

Stopień dyfuzorowości kanału przepływowego dyfuzora zakrzywionego:

$$
\bar{F}_{5,4}=\frac{F_{5,1}}{F_{4,1}}
$$

Stopień dyfuzorowości kanału dyfuzora zakrzywionego powinien spełniać relację $\bar{F}_{5,4} \leq 7$ [3]. 


\section{Parametry geometryczne dyfuzora zakrzywionego}

Wylot dyfuzora zakrzywionego charakteryzuje się kształtem (zarysem) oraz średnicą zewnętrzną $D_{5 z}$ i wewnętrzną $D_{5 w}$ (rys. 4.). Średnice te określają średnicę średnią arytmetyczną

$$
D_{5 s ́ r}=\frac{D_{5 Z}+D_{5 w}}{2}
$$

oraz promień średni

$$
R_{5 \dot{s} r}=\frac{D_{5 s ́}}{2}
$$

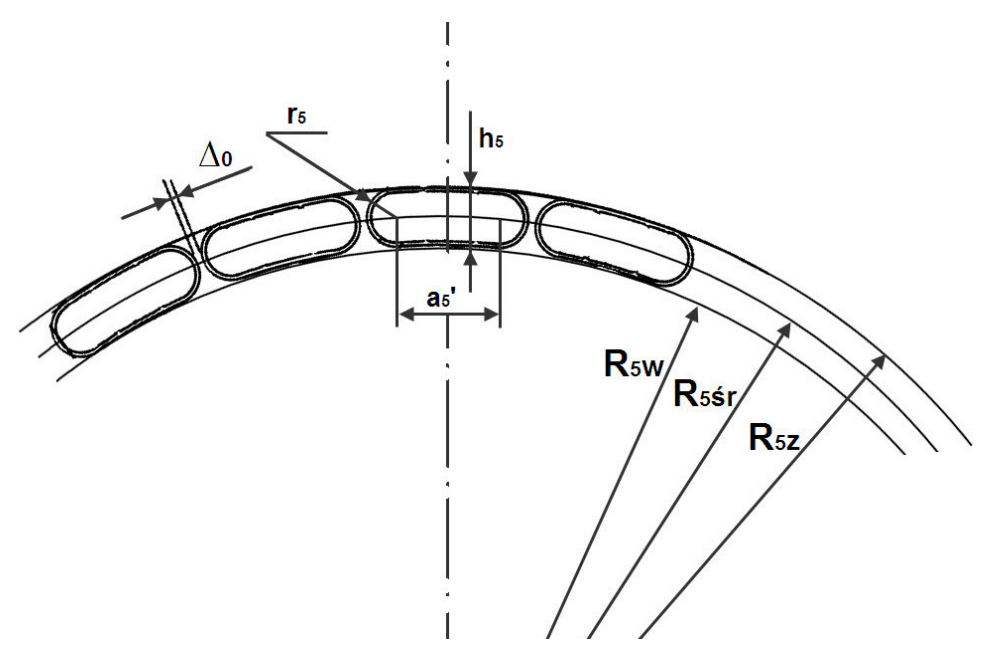

Rys. 4. Schemat ilustrujący rozmieszczenie wylotów dyfuzorów zakrzywionych

Fig. 4. Scheme illustrating the arrangement of the controlled-contour diffuser outlets

Przyjmując zarys wylotu pojedynczego kanału dyfuzora zakrzywionego jako prostokątny z dwoma promieniami (rys. 4.) oraz grubość blachy ścianki $g=0,6 \div 1,2 \mathrm{~mm}$, pole powierzchni $F_{5,1}$ można wyrazić następująco:

$$
F_{5,1}=h_{5} \cdot a^{\prime}+\pi r_{5}^{2}
$$

gdzie promień wylotu kanału $r_{5}$ oraz wysokość kanału wylotowego $h_{5}$ wiąże zależność

$$
h_{5}=2 r_{5}
$$

natomiast przez $a_{5}^{\prime}$ oznaczono podstawę prostokąta. 
Biorąc pod uwagę oczywistą relację

$$
\frac{\pi D_{5 s} r}{Z_{D z}}-\left(\Delta_{0}+2 g\right) Z_{D z}=a_{5}^{\prime}+2 r_{5}
$$

gdzie luz obwodowy $\Delta_{0}=0 \div 4 g$ [4], otrzymuje się:

$$
a_{5}^{\prime}=\frac{\pi D_{5 s ́ r}}{Z_{D z}}-\left(\Delta_{0}+2 g\right) Z_{D z}-2 r_{5}
$$

Po podstawieniu formuły (25) do wzoru (22) i prostych przekształceniach promień wylotu kanału dyfuzora zakrzywionego oblicza się z równania kwadratowego:

$$
(\pi-4) r_{5}^{2}+\left[\frac{2 \pi D_{5 s} r}{Z_{D z}}-2\left(\Delta_{0}+2 g\right) Z_{D z}\right] r_{5}-F_{5,1}=0
$$

Długość prostoliniowej podstawy prostokąta $a_{5}^{\prime}$ wyznacza się z zależności (25), wysokość zaś kanału wylotowego $h_{5}$ ze wzoru (23), przy czym zazwyczaj $h_{5}=(0,7 \div 1,15) d_{4}[3-5]$.

Profilowanie dyfuzora zakrzywionego może przebiegać w następującej kolejności: przyjmuje się długość osi kanału przepływowego dyfuzora zakrzywionego $l_{Z}=(10 \div 12,5) d_{4}$ oraz jej składowe odcinki prostoliniowe $C-A^{\prime}$ o długości $l_{1}=(2 \div 4) d_{4}$ [5] i B'-5 o długości $l_{2}=(2,3 \div 4,2) d_{4}$, a także eliptyczny przebieg zagięcia (rys. 5.).

Rys. 5. Schemat ilustrujący parametry geometryczne dyfuzora zakrzywionego

Fig. 5. Scheme illustrating geometrical parameters of the controlled-contour diffuser

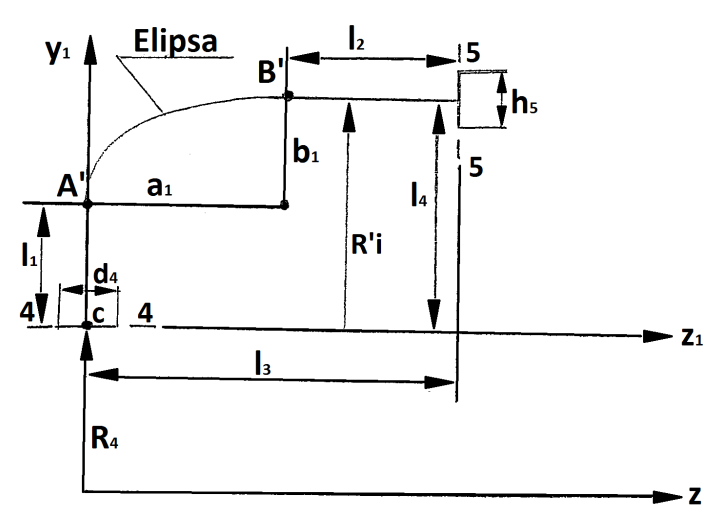

W celu określenia wartości półosi małej elipsy zakrzywienia dyfuzora zakrzywionego $b_{1}$

$$
b_{1}=l_{4}-l_{1}
$$


oraz półosi wielkiej elipsy $a_{1}$ zakrzywienia dyfuzora zakrzywionego

$$
a_{1}=l_{3}-l_{2}
$$

niezbędna jest znajomość długości odcinków $l_{3}$ i $l_{4}$. Zazwyczaj przyjmuje się $l_{3}=(6 \div 9,5) d_{4}$, natomiast $l_{4}=(5 \div 9) d_{4}[3-6]$.

Promień $R_{i}^{\prime}$ stanowiący miarę odległości punktu osi dyfuzora zagiętego od osi $z_{1}$, pomocniczego układu współrzędnych $\left(x_{1}, y_{1}, z_{1}\right)$, równoległej do osi $z$ (osi obrotu wirnika), głównego układu współrzędnych $(x, y, z)$ zmienia się następująco:

- na odcinku prostoliniowym $C A^{\prime}$ promień $R_{i}^{\prime} \in\left(0, l_{1}\right)$,

- na odcinku krzywoliniowym $A^{\prime} B^{\prime}$ promień $R_{i}^{\prime}$ wyznacza formuła

$$
R_{i}^{\prime}=l_{1}+y_{1}
$$

gdzie współrzędną $y_{1}$ określa się z równania elipsy

$$
\left(\frac{z_{1}}{a_{1}}\right)^{2}+\left(\frac{y_{1}}{b_{1}}\right)^{2}=1
$$

skąd

$$
y_{1}=b_{1} \sqrt{1-\frac{z_{1}^{2}}{a_{1}^{2}}}
$$

zmienia się w zależności od przyjętej wartości współrzędnej $z_{l} \in\left(0, a_{l}\right)$,

- na odcinku prostoliniowym $B^{\prime} 5$ promień $R i^{\prime}$ określa zależność

$$
R_{i}^{\prime}=l_{1}+b_{1}
$$

Ponieważ obwód $O$ elipsy wyznacza wzór

$$
\begin{aligned}
& O=\pi\left[3\left(a_{1}+b_{1}\right)-\sqrt{\left(3 a_{1}+b_{1}\right)\left(a_{1}+3 b_{1}\right)}\right] \\
& \approx \pi\left[\frac{3}{2} \pi\left(a_{1}+b_{1}\right)-\sqrt{a_{1} b_{1}}\right]
\end{aligned}
$$

rzeczywistą długość osi kanału dyfuzora sprawdza się następująco:

$$
l_{z}=l_{1}+\frac{\pi}{4}\left[\frac{3}{2}\left(a_{1}+b_{1}\right)-\sqrt{a_{1} b_{1}}\right]+l_{2}
$$


Powinna być spełniona zależność $l_{z}=(10 \div 12,5) d_{4}$. Jeżeli warunek ten nie jest spełniony, należy zwiększyć wartość $l_{3}$ lub $l_{4}$.

W celu określenia wartości współrzędnych kanału przepływowego dyfuzora zakrzywionego niezbędna jest znajomość odległości $R_{i}$ osi dyfuzora zakrzywionego (przechodząca przez środki geometryczne powierzchni przekroju poprzecznego) od osi obrotu wirnika - oś $z$ głównego układu współrzędnych dyfuzora zakrzywionego (rys. 6.). Należy zauważyć, że pomocniczy układ współrzędnych $\left(x_{1}, y_{1}, z_{1}\right)$, w którym wymiaruje się dyfuzor zakrzywiony, oraz główny układ współrzędnych $(x, y, z)$ są ze sobą ściśle związane, ponieważ równoległe osie $z_{1}$ i $z$ obu układów są położone względem siebie w odległości promienia $R_{4}$ (rys. 2. i 7.).

Rys. 6. Główny układ współrzędnych kanału przepływowego dyfuzora zakrzywionego

Fig. 6. Main coordinate system of the flow passage of the controlled-contour diffuser

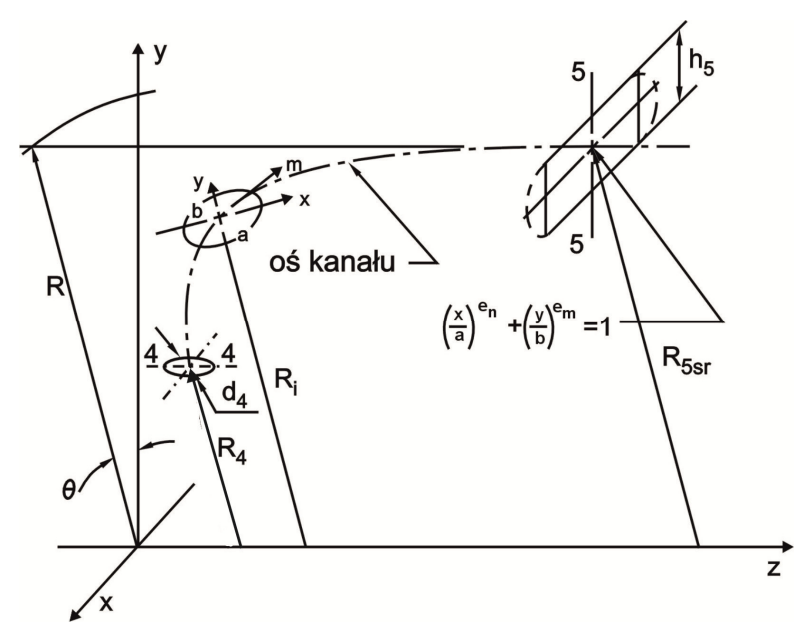

Rys. 7. Wzajemne usytuowanie pomocniczego i głównego układu współrzędnych

Fig. 7. The mutual position of the auxiliary and main coordinate system

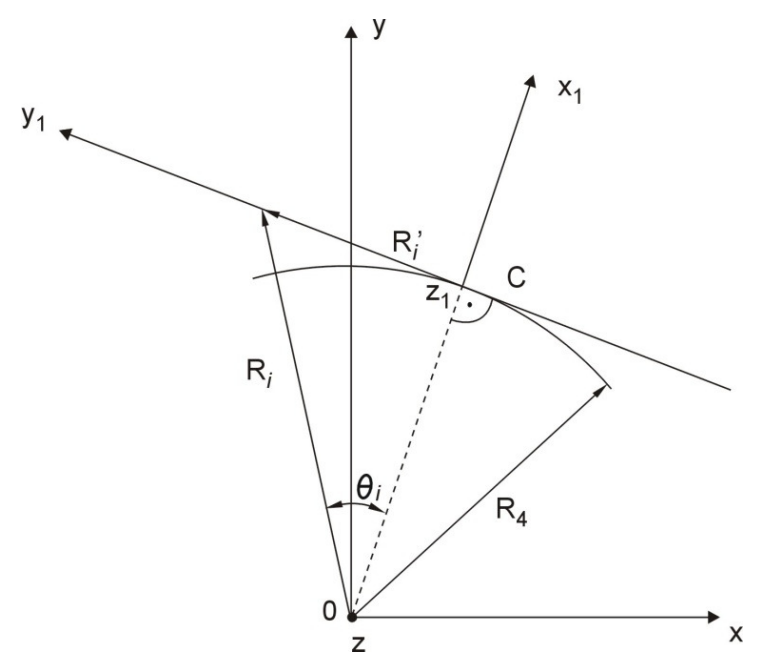


Pomocniczy układ współrzędnych dyfuzora zakrzywionego, w którym jest zdefiniowana jego geometria, jest odsunięty od osi $z$ obrotu wirnika sprężarki o wartość promienia wylotu z dyfuzora rurkowego $R_{4}$, a współrzędne osi $z_{1}$ i $z$ są tożsame

$$
z \equiv z_{1}
$$

Równanie przejścia od układu pomocniczego do układu głównego, umożliwiającego określenie promienia $R i$ osi dyfuzora zakrzywionego (odległości punktu osi dyfuzora od osi z), zgodnie z twierdzeniem Pitagorasa przyjmuje postać:

$$
R_{i}=\sqrt{R_{4}^{2}+R_{i}^{\prime 2}}
$$

Kąt skierowany (amplitudę punktu osi dyfuzora zakrzywionego) wyznacza formuła:

$$
\Theta_{i}=\operatorname{arctg} \frac{R_{i}^{\prime}}{R_{4}}
$$

Promień średni wylotu dyfuzora zakrzywionego (odległość końcowego punktu osi dyfuzora od osi $z$ w przekroju 5-5) określa relacja:

$$
R_{5 s i r}=\sqrt{R_{4}^{2}+l_{4}^{2}}
$$

Zatem promienie zewnętrzny i wewnętrzny:

$$
\begin{aligned}
& R_{5 z}=R_{5 s i r}+\frac{h_{5}}{2} \\
& R_{5 w}=R_{5 s i r}-\frac{h_{5}}{2}
\end{aligned}
$$

Wartość promienia średniego uzyskana ze wzoru (38) powinna być równa wartości tego promienia określonej z zależności (21). Średnice zewnętrzna $D_{5 z}=2 R_{5 z}$ oraz wewnętrzna $D_{5 w}=2 R_{5 w}$ powinny mieć zbliżone wartości do przyjętych ze względów konstrukcyjnych komory spalania. Przy znacznej różnicy wartości promienia średniego, określonej z formuł (38) oraz (21), należy zmienić wartości $l_{4}$. W celu wyznaczenia bieżących, rosnących wartości pól powierzchni przekroju poprzecznego dyfuzora zakrzywionego $F_{i}$ pomiędzy przekrojem wejściowym (4-4) a przekrojem wyjściowym (5-5) można zakładać liniową zmianę wysokości kanału przepływowego dyfuzora od wartości $d_{4}$ na wlocie do wartości $h_{5}$ na jego wylocie (rys. 8.). 


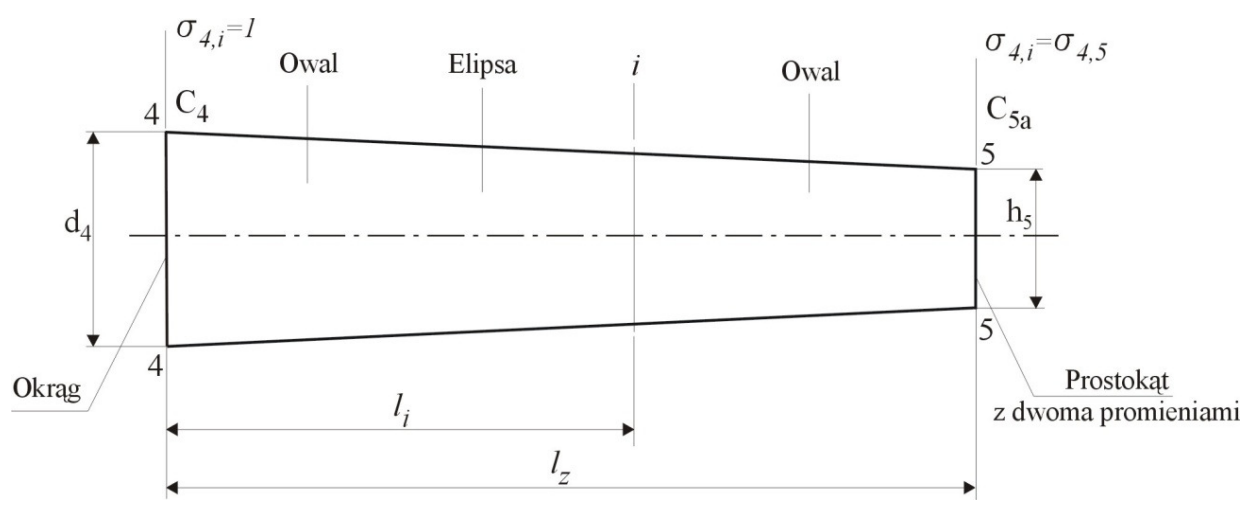

Rys. 8. Schemat ilustrujący zmianę wysokości kanału dyfuzora zakrzywionego

Fig. 8. Scheme illustrating the change of height of the controlled-contour diffuser duct

\section{Parametry strumienia $w$ przekrojach pośrednich dyfuzora}

Przyjmując liczbę przekrojów kontrolnych $(I=6 \div 10)$ dyfuzora zakrzywionego oraz ich odległości od przekroju wlotowego $l_{i}$ (z przedziału $l_{i} \in\left(0, l_{z}\right)$ ), wyznacza się wartości stopnia strat ciśnienia spiętrzenia od przekroju wlotowego (4-4) do bieżącego (i-i) z zależności:

$$
\sigma_{4, i}=\sigma_{4,5}+\frac{\left(l_{z}-l_{i}\right)}{l_{z}}\left(1-\sigma_{4,5}\right)
$$

gdzie

$$
\sigma_{4, i}=\frac{p_{i}^{*}}{p_{4}^{*}}
$$

Znajomość wartości stopnia strat ciśnienia spiętrzenia $\sigma_{4, i}$ umożliwia wyznaczenie ciśnienia spiętrzenia $\mathrm{w}$ dowolnym przekroju $(i-i)$ dyfuzora:

$$
p_{i}^{*}=\sigma_{4, i} \cdot p_{4}^{*}
$$

Zakładając liniową zmianę wartości prędkości bezwzględnej w dyfuzorze, oblicza się jej wartość w dowolnym przekroju:

$$
C_{i}=C_{5}+\frac{l_{z}-l_{i}}{l_{z}}\left(C_{4}-C_{5}\right)
$$

Wiąże się to z przyjęciem założenia $C_{i}=C_{a i}$ oraz $C_{5}=C_{5 a}$. 
Ponieważ w dyfuzorze występuje przepływ energetycznie odosobniony (izoenergetyczny), temperatura spiętrzenia zachowuje wartość stałą:

$$
T_{i}^{*}=T_{4}^{*}=T_{5}{ }^{*}
$$

Prędkość krytyczna dźwięku wynosi:

$$
a_{k r i}=\sqrt{\frac{2 k R}{k+1} T_{i}^{*}}
$$

Liczbę Lavala prędkości bezwzględnej określa się ze związku definicyjnego:

$$
\lambda_{i}=\frac{C_{i}}{a_{k r i}}
$$

Znajomość liczby Lavala $\lambda_{i}$ umożliwia wyznaczenie wartości funkcji gazodynamicznych temperatury i ciśnienia z zależności definicyjnych [7]:

$$
\begin{aligned}
& \tau\left(\lambda_{i}\right)=\left(1-\frac{k-1}{k+1} \lambda_{i}^{2}\right) \\
& \pi\left(\lambda_{i}\right)=\left(1-\frac{k-1}{k+1} \lambda_{i}^{2}\right)^{\frac{k}{k-1}}
\end{aligned}
$$

Temperaturę statyczną i ciśnienie statyczne oblicza się z równości:

$$
\begin{aligned}
& T_{i}=T_{i}^{*} \tau\left(\lambda_{i}\right) \\
& p_{i}=p_{i}^{*} \pi\left(\lambda_{i}\right)
\end{aligned}
$$

Liczba Macha strumienia wynika ze wzoru definicyjnego:

$$
M_{i}=\frac{C_{i}}{\sqrt{k R T_{i}}}
$$

natomiast gęstość statyczną czynnika wyznacza się z równania stanu:

$$
\rho_{i}=\frac{p_{i}}{R T_{i}}
$$


Względną gęstość strumienia masy określa formuła:

$$
q\left(\lambda_{i}\right)=\lambda_{i}\left(1-\frac{k-1}{k+1} \lambda_{i}^{2}\right)^{\frac{1}{k-1}}\left(\frac{k+1}{2}\right)^{\frac{1}{k-1}}
$$

Pole powierzchni dowolnego przekroju poprzecznego pojedynczego kanału przepływowego dyfuzora zagiętego wyznacza się z równania ciągłości:

$$
F_{i, 1}=\frac{\dot{m} \sqrt{T_{i}^{*}}}{z_{D z} s p_{i}^{*} q\left(\lambda_{i}\right) \sin \alpha_{i} K m_{i}}
$$

gdzie $F_{i} \in\left(F_{4,1}, F_{5,1}\right)$ oraz $z_{D z}=z_{D r}$, natomiast $\mathrm{w}$ relacji (55) przyjmuje się wartość kąta $\alpha_{i}=90^{\circ}$.

Przepływowi powietrza przez dyfuzor zakrzywiony, podobnie jak każdemu przepływowi przez kanał zakrzywiony, towarzyszą przepływy wtórne. W rezultacie przepływów wtórnych torami cząstek są linie śrubowe, stąd prędkość bezwzględna strumienia w dowolnym przekroju (i-i) dyfuzora zakrzywionego ma dwie składowe: osiową $C_{a i}$ (wzór (44)) oraz obwodową $C_{u i}$, którą wyznacza się $\mathrm{z}$ równania ilości ruchu Eulera (dla przepływu bez tarcia):

$$
C_{u i}=\frac{C_{4 u} R_{4}}{R_{i}}
$$

Kąt kierunkowy prędkości bezwzględnej opisuje wyrażenie:

$$
\alpha_{i}=\operatorname{arctg} \frac{C_{a i}}{C_{u i}}
$$

\section{Profilowanie zarysu zewnętrznego}

Zespół dyfuzorów zakrzywionych jest układem wylotowym sprężarki promieniowej lub osiowo-promieniowej z dyfuzorem rurkowym. Dyfuzory są stosowane w sprężarkach tych typów ze względu na zwartość konstrukcji. W zestawieniu z dyfuzorem rurkowym pozwala na uzyskanie znacząco mniejszej średnicy zewnętrznej sprężarki na wylocie nawet do 20\% [3], co prowadzi bezpośrednio do zmniejszenia masy sprężarki silnika śmigłowego i śmigłowcowego, a w przypadku silnika dwuprzepływowego dodatkowo do wzrostu ciągu czołowego. Dysponując określoną długością w kierunku osiowym, przepływający czynnik można bardziej opóźnić w dyfuzorze zakrzywionym niż w układzie 
wylotowym sprężarki innego typu. Dyfuzor zakrzywiony pozwala bowiem uzyskiwać stopień dyfuzorowości o bardzo wysokiej wartości $\bar{F}_{5,4} \leq 7$ [3].

Pomocniczy układ współrzędnych $x_{1}, y_{1}, z_{1}$ dyfuzora zakrzywionego połączono ze środkiem kanału dyfuzora rurkowego na jego wylocie (rys. 2.), oś $y_{1}$ ma zaś kierunek osi symetrii tego dyfuzora. Układ współrzędnych przyjęty w taki sposób stanowi podstawę identyfikacji parametrów geometrycznych kanału dyfuzora zagiętego. Profilowanie zarysu zewnętrznego kanału przepływowego dyfuzora zakrzywionego w przekrojach pośrednich prowadzi się, mając na uwadze fakt, że pole powierzchni przekroju poprzecznego pojedynczego kanału dyfuzora zakrzywionego na wlocie $F_{4,1}$ jest znane z obliczeń dyfuzora rurkowego, jego zarys zewnętrzny stanowi zaś okrąg o średnicy $d_{4}$. Znane jest również pole powierzchni przekroju poprzecznego pojedynczego kanału dyfuzora zakrzywionego na wylocie $F_{5,1}$ (wzór (17)), jego zarys zewnętrzny i parametry geometryczne, tj. wartość podstawy prostokąta $a_{5}^{\prime}=2 a_{5}$ oraz promień zaokrąglenia $r_{5}$ (rys. 4.). Znajomość wartości pola powierzchni dowolnego przekroju poprzecznego pojedynczego kanału przepływowego dyfuzora zakrzywionego $F_{i, 1}$, przy znanej wartości półosi małej owalu:

$$
b_{i}=\frac{h_{i}}{2}
$$

gdzie wysokość kanału dyfuzora zakrzywionego w punkcie (i-i)

$$
h_{i}=d_{4}-\left(d_{4}-h_{5}\right) \frac{l_{i}}{l_{z}}
$$

pozwala na przyjęcie wartości półosi wielkiej owalu $a_{i}$ z przedziału $a_{i} \in\left(d_{4} / 2\right.$, $a_{5}$ ) (rys. 9.).

Dysponowanie wartościami półosi owalu $a_{i}$ oraz $b_{i}$ umożliwia wyznaczenie współrzędnych owalnego zarysu zewnętrznego kanału przepływowego dyfuzora zakrzywionego $\mathrm{w}$ przekrojach pośrednich według równania podanego $\mathrm{w}$ pracy [3]:

$$
\left(\frac{x_{i}}{a_{i}}\right)^{e n}+\left(\frac{y_{i}}{b_{i}}\right)^{e m}=1
$$

Wartości wykładników $e_{n}$ i $e_{m}$ przyjmuje się równe 2 dla elipsy, dla zaś owali leżących w pobliżu wylotu dyfuzora 8 (i więcej). Pola powierzchni poszczególnych owali zarysu zewnętrznego kanału przepływowego dyfuzora określa się przez planimetrowanie, a ich wartości powinny być zbliżone do wartości $F_{i, 1}$ wyznaczonych z równania ciągłości (wzór (55)). Płynność przebiegu kanału przepływowego dyfuzora zakrzywionego można sprawdzić za pomocą zinte- 
growanych systemów trójwymiarowego modelowania 3D (CATIA, Unigraphics) (rys. 9.).

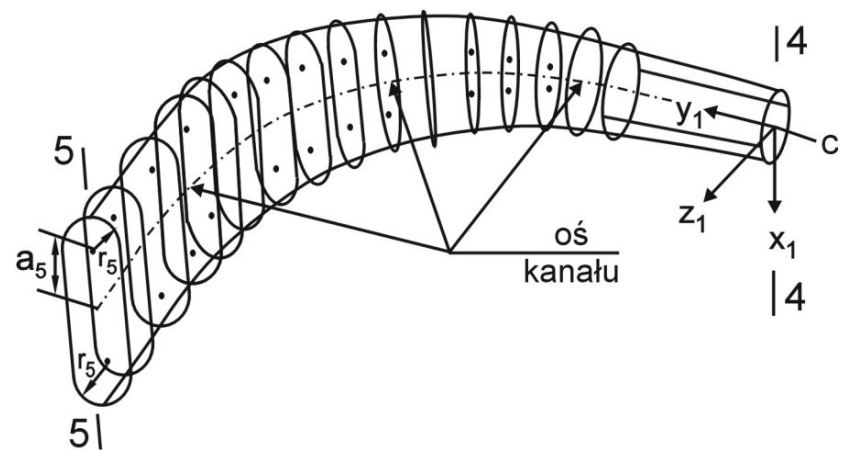

Rys. 9. Schemat ilustrujący sprawdzenie płynności przebiegu kanału przepływowego dyfuzora zakrzywionego, na podstawie [5]

Fig. 9. Scheme illustrating the check of smoothness of fishtail diffuser flow duct course, according to [5]

W pracy [5] przyjęto liniową zmienność pola powierzchni kanału przepływowego dyfuzora zakrzywionego:

$$
F_{i, 1}=F_{4}+\left(F_{5}-F_{4}\right) \frac{l_{i}}{l}
$$

Należy zauważyć, że pojedynczy kanał dyfuzora zakrzywionego według patentu Vrany [6] miał obrys ścianek w przekroju poprzecznym o zarysie kołowym, według zaś patentu [4] - zarys przedstawiony na rys. 1., 4. oraz 9. Skąpa liczba informacji dotyczących zagadnień obliczania parametrów i profilowania dyfuzora zakrzywionego w dostępnej literaturze przedmiotu zmusiła autora niniejszej pracy do poszukiwania własnej drogi postępowania, która daje możliwość skutecznego operowania zmianami parametrów strumienia oraz geometrycznymi kanału przepływowego z dostateczną dokładnością dla praktyki inżynierskiej.

\section{Uwagi końcowe}

Wartość sprężu zarówno sprężarki promieniowej, jak i osiowo-promieniowej $\pi_{S o}^{*}$ powinna być większa od wartości sprężu sprężarki $\pi_{S}^{*}$ zadanej w obliczeniach termo-gazodynamicznych silnika, a odpowiadającej wartości tego parametru na linii współpracy sprężarki i turbiny. W lotniczym silniku turbinowym sprężarka bezpośrednio współpracuje z zasilanym przez nią całym kanałem przepływowym silnika, stanowiącym układ dławiący (przepustnicę na 
wylocie ze sprężarki). W układzie silnika wartość sprężu sprężarki $\pi_{S}^{*}$ określa się zwykle podczas prób odbiorczych, mierząc jego wartość na linii współpracy sprężarki z napędzającą sprężarkę turbiną.

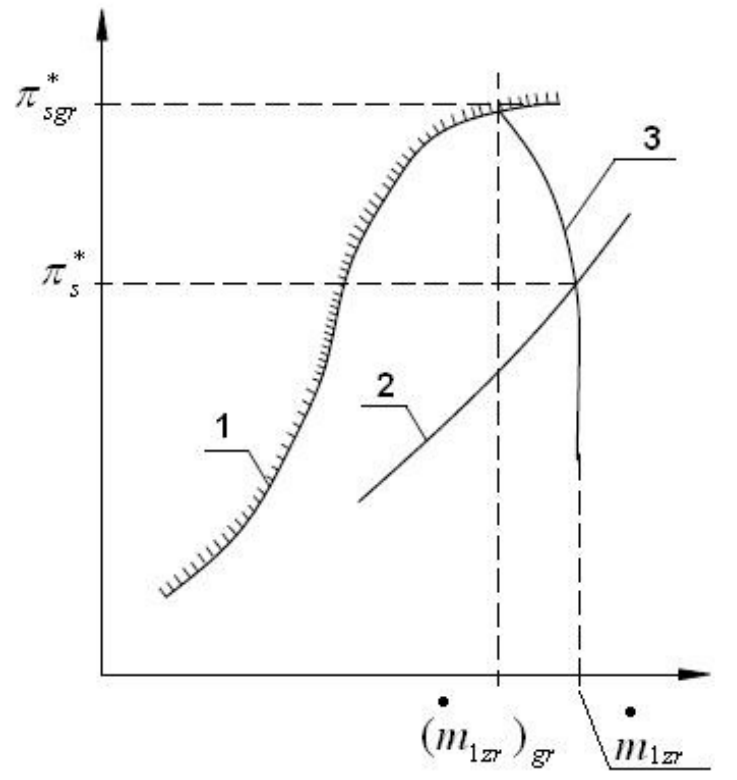

Rys. 10. Ilustracja określenia zapasu statecznej pracy sprężarki: 1 - granica pracy statecznej, 2 - linia współpracy S-TS, 3 - krzywa dławienia $n_{\text {Szr }}=$ idem

Fig. 10. Illustration of determination for surge margin compressor: 1 - surge line, 2 - working line, 3 - corrected speed of impeller $n_{S z r}=$ idem

Ilościową ocenę odległości linii współpracy S-TS od granicy statecznej pracy sprężarki (rys. 10.) umożliwia zapas statecznej pracy sprężarki, zdefiniowany wyrażeniem [8]:

$$
\Delta K_{S}=\frac{\pi_{S g r}^{*} /\left(\dot{m}_{1 z r}\right)_{g r}-\pi_{S}^{*} / \dot{m}_{1 z r}}{\pi_{S}^{*} / \dot{m}_{1 z r}}
$$

gdzie: $\dot{m}_{1 z r}$ i $\left(\dot{m}_{1 z r}\right)_{g r}$ - odpowiednio zredukowany strumień masy powietrza określony na wlocie do sprężarki w punkcie współpracy i na granicy statecznej pracy przy $n_{S z r}=$ idem; $\pi_{S}^{*}$ i $\pi_{S g r}^{*}$ - odpowiednio spręż sprężarki na linii współpracy S-TS i na granicy statecznej pracy przy $n_{S z r}=i d e m$.

W zależności od typu konstrukcyjnego sprężarki, sposobu regulacji i zastosowania silnika zapas statecznej pracy wynosi zwykle $\Delta K_{S}=0,1 \div 0,2$ dla sprężarek promieniowych oraz $\Delta K_{S}=0,15 \div 0,25$ [8] dla osiowych. Badania eksperymentalne sprężarek promieniowych $\mathrm{z}$ dyfuzorami rurkowymi wykazały silny wpływ liczby Macha prędkości strumienia w przekroju wejściowym, tj. gardzieli dyfuzora rurkowego $M_{3}$ na przebieg krzywej dławienia sprężarki. Przebieg krzywej dławienia sprężarki promieniowej dla wybranej, obliczeniowej prędkości obrotowej charakteryzuje minimalna wartość strumienia masy powietrza w przekroju wejściowym sprężarki $\dot{m}_{1 \min }=\left(\dot{m}_{1 \mathrm{zr}}\right)_{g r}$, odpowiadająca mak- 
symalnej wartości jej sprężu $\pi_{S \max }^{*}=\pi_{S g r}^{*}$ oraz maksymalnej wartości strumienia masy powietrza $\mathrm{w}$ przekroju wejściowym sprężarki $\dot{m}_{1 \text { max }}=\dot{m}_{1 \mathrm{zr}}$ stanowiąca odciętą pionowego odcinka charakterystyki, którego rzędna w najwyższym punkcie odpowiada sprężowi $\pi_{S}^{*}$ na linii współpracy S-TS. Rysunek 11. ilustruje zależność $\frac{\dot{m}_{1 \max }-\dot{m}_{1 \min }}{\dot{m}_{1 \max }}=f\left(M_{3}, i_{3}\right)$ uzyskaną z rezultatu badań eksperymentalnych sprężarek odśrodkowych zawierających dyfuzory rurkowe o różnych kształtach kanałów przepływowych w przekroju poprzecznym [9].

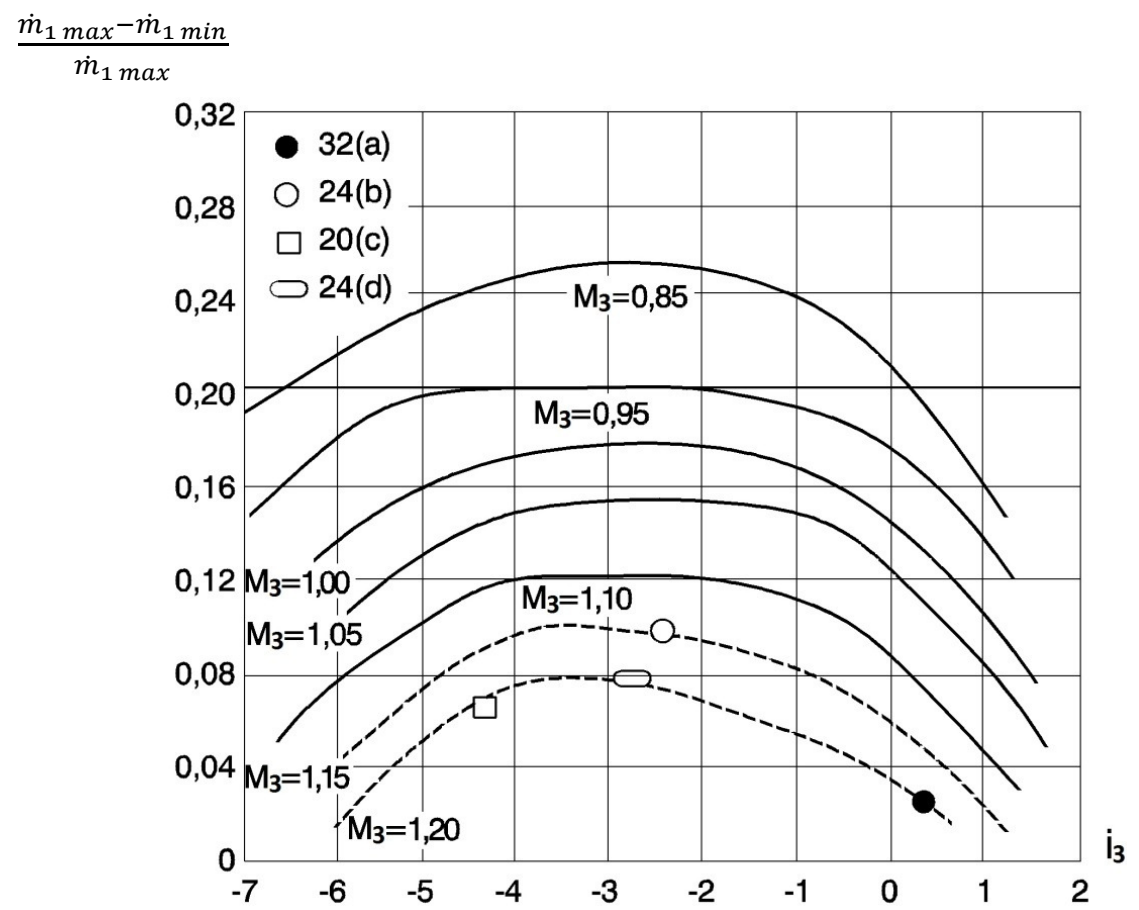

Rys. 11. Przebiegi ilorazu $\frac{\dot{m}_{1 \max }-\dot{m}_{1 \min }}{\dot{m}_{1 \max }}$ od liczby Macha $M_{3}$ oraz kąta natarcia $i_{3} \mathrm{w}$ dyfuzorach rurkowych o różnych kształtach gardzieli i liczbie kanałów: a) $z_{D r}=32$, gardziel kołowa, b) $z_{D r}=24$ gardziel kołowa, c) $z_{D r}=20$ gardziel kwadratowa, d) $z_{D r}=24$ gardziel owalno-prostokątna, $z_{D r}$ - liczba kanałów dyfuzora rurkowego, na podstawie [9]

Fig. 11. Courses of quotient $\frac{\dot{m}_{1 \max }-\dot{m}_{1 \min }}{\dot{m}_{1 \max }}$ versus Mach number $M_{3}$ and incidence angle $i_{3}$ for pipe diffusers with different throat shapes and number of passages: a) $z_{D r}=32$, circular throat, b) $z_{D r}=24$ circular throat, c) $z_{D r}=20$ square throat, d) $z_{D r}=24$ ovalrectangular throat, $z_{D r}$ - passage number of pipe diffuser, according to [9]

$\mathrm{Z}$ rysunku 11. wynika, że wraz ze wzrostem wartości liczby Macha w przekroju wyjściowym dyfuzora bezłopatkowego $M_{3}$ maleje wartość parametru 
$\frac{\dot{m}_{1 \max }-\dot{m}_{1 \min }}{\dot{m}_{1 \max }}$, dla zaś $M_{3}=1,2$ oraz kąta natarcia $i_{3}>0$ krzywa dławienia przebiega niemal pionowo. Spręż obliczeniowy, na którego wartość projektuje się sprężarkę promieniową, powinien zapewniać jej pracę z zadowalającą wartością zapasu statecznej pracy. Wzór $\pi_{S g r}^{*}=\pi_{S o}^{*}$ i relację (60) można więc zapisać w następującej postaci:

$$
\Delta K_{S}=\frac{\pi_{S o}^{*} / \dot{m}_{1 \min }-\pi_{S}^{*} / \dot{m}_{1 \max }}{\pi_{S}^{*} / \dot{m}_{1 \max }}
$$

skąd obliczeniowa wartość sprężu sprężarki promieniowej

$$
\pi_{S o}^{*}=\frac{\left(1+\Delta K_{S}\right) \pi_{S}^{*}}{1+\left(\dot{m}_{1 \max }-\dot{m}_{1 \min }\right) / \dot{m}_{1 \min }}
$$

lub

$$
\pi_{S o}^{*}=\frac{\left(1+\Delta K_{S}\right) \pi_{S}^{*}}{1+\bar{m}}
$$

gdzie

$$
\bar{m}=\frac{\dot{m}_{1 \max }-\dot{m}_{1 \min }}{\dot{m}_{1 \min }}
$$

W przypadku sprężarki promieniowej z dyfuzorem rurkowym znany jest przebieg ilorazu (rys. 11.):

$$
\bar{m}_{1}=\frac{\dot{m}_{1 \max }-\dot{m}_{1 \min }}{\dot{m}_{1 \max }}
$$

Zatem po uwzględnieniu formuły (64) otrzymuje się:

$$
\bar{m} \dot{m}_{1 \min }=\bar{m}_{1} \dot{m}_{1 \max }
$$

Ponieważ z relacji (65) wynika bezpośrednio

$$
\dot{m}_{1 \min }=\dot{m}_{1 \max }\left(1-\bar{m}_{1}\right)
$$

po podstawieniu zależności (67) do wzoru (66) uzyskuje się:

$$
\bar{m}=\frac{\bar{m}_{1}}{1-\bar{m}_{1}}
$$

Uwzględniając wzór (68), obliczeniową wartość sprężarki promieniowej z dyfuzorem rurkowym można wyznaczyć z formuły:

$$
\pi_{S o}^{*}=\left(1+\Delta K_{S}\right) \pi_{S}^{*}\left(1-\bar{m}_{1}\right)
$$


Ze wzoru (69) jest wyznaczana obliczeniowa wartość sprężu sprężarki promieniowej z dyfuzorem rurkowym po przyjęciu wartości jej zapasu statecznej pracy $\Delta K_{S}$. Z obliczeń dyfuzora bezłopatkowego są znane parametry strumienia w jego przekroju wyjściowym (3-3), tj. wartość liczby Macha prędkości bezwzględnej $C_{3}-M_{3}$ oraz kąt kierunkowy tej prędkości $\alpha_{3}$. Niezbędną do określenia wartości parametru $\bar{m}_{1}$ (rys. 11.) wartość kąta natarcia $i_{3}$ wyznacza się według formuły (9):

$$
i_{3}=\alpha_{3 K}-\alpha_{3}
$$

gdzie kąt konstrukcyjny określa relacja [10]

$$
\alpha_{3 K}=\arccos \frac{R_{2}}{R_{3}}
$$

Sprężarka osiowo-odśrodkowa jest najkorzystniejszym wariantem dla silników turbinowych o małych strumieniach masy powietrza $\dot{m}=2 \div 6 \mathrm{~kg} / \mathrm{s}$ i umiarkowanych sprężach $6 \leq \pi_{S}^{*} \leq 12$. W sprężarce osiowej dla tych wydatków i spręży łopatki końcowych stopni są zbyt krótkie, co wpływa ujemnie na wartość jej sprawności izentropowej. Szczegółową procedurę podziału sprężu sprężarki osiowo-promieniowej $-\pi_{S}^{*}$ pomiędzy część osiową $-\pi_{S A}^{*}$ i odśrodkową $-\pi_{S R}^{*}$ podano w pracy [11]. Ponieważ spręż sprężarki osiowo-promieniowej jest iloczynem spręży jej części składowych:

$$
\pi_{S}^{*}=\pi_{S A}^{*} \pi_{S R}^{*}
$$

Zatem obliczeniową wartość sprężu sprężarki osiowo-promieniowej określa relacja:

$$
\pi_{S o}^{*}=\left(\pi_{S A}^{*}\right)_{0} *\left(\pi_{S R}^{*}\right)_{0}
$$

gdzie obliczeniowa wartość sprężu części osiowej sprężarki jest wyznaczana analogicznie do sprężarki osiowej.

$$
\left(\pi_{S A}^{*}\right)_{0}=\pi_{S A}^{*}\left(1+\frac{\pi_{S A}^{*}}{100}\right)
$$

Obliczeniową wartość sprężu części promieniowej sprężarki osiowo-odśrodkowej $\left(\pi_{S R}^{*}\right)_{0}$ wyznacza się z formuły (69).

Obliczenia układu wylotowego, a zarazem obliczenia przepływowe sprężarki promieniowej lub osiowo-promieniowej można uważać za poprawne, jeśli w rezultacie obliczeń uzyskano rzeczywistą wartość sprężu obliczeniowego sprężarki, definiowanego jako stosunek ciśnienia spiętrzenia w przekroju wyjściowym układ wylotowego $-p_{w y l}^{*}$ do ciśnienia spiętrzenia w przekroju wejściowym sprężarki $-p_{1}^{*}$ : 


$$
\left(\pi_{S o}^{*}\right)_{r z}=\frac{p_{w y l}^{*}}{p_{1}^{*}}
$$

zbliżoną do wartości teoretycznej (wzór (69) lub (73)). Zaleca się, aby błąd względny wartości wymienionych spręży nie przekraczał dla projektu wstępnego $1 \%$ [12], dla zaś projektu koncepcyjnego 5\% [13]. Jeżeli błąd względny rzeczywistej wartości sprężu obliczeniowego (wzór (75)) oraz wartości teoretycznej przyjętej na początku obliczeń przepływowych sprężarki (formuła (69) lub (73)) przekracza wartość dopuszczalną, wówczas obliczenia sprężarki należy powtórzyć, przyjmując inną wartość sprawności hydraulicznej - mniejszą przy $\left(\pi_{S o}^{*}\right)_{r z}<\pi_{S o}^{*}$ i większą przy $\left(\pi_{S o}^{*}\right)_{r z}>\pi_{S o}^{*}$.

Należy także zauważyć, że dopiero dysponowanie charakterystyką eksperymentalną (uniwersalną) sprężarki umożliwia projektantowi sprawdzenie wartości zapasu statecznej pracy sprężarki dla zakresu obliczeniowego (np. startowego), którego współrzędne w punkcie współpracy (rys. 10.) określają wartość zredukowanego strumienia masy powietrza na wlocie do sprężarki $\dot{m}_{1 z r}$ oraz spręż sprężarki $\pi_{S}^{*}$, określone na linii współpracy sprężarki S-TS. Według autorów pracy [14] praktyka projektowa w Anglii dopuszcza dodatkowe kryterium stosunku wartości strumienia masy powietrza w punkcie współpracy, a mianowicie $\dot{m}_{1 z r} / \dot{m}_{1 \text { max }} \approx 0,92$ dla sprężarek promieniowych $\mathrm{z}$ dyfuzorem łopatkowym, natomiast w Stanach Zjednoczonych dla sprężarek promieniowych (z dyfuzorami promieniowymi wszystkich typów) zaleca się spełnienie relacji przybliżonej $\dot{m}_{1 \mathrm{zr}} / \dot{m}_{1 \text { max }} \approx 0,98$.

\section{Literatura}

[1] Kenny D.P.: A novel low-cost diffuser for high-performance centrifugal compressors. Trans. ASME, J. Eng Power, 1 (1969), 37-47.

[2] Antas S., Lesikiewicz A.: Teoria silników przepływowych. Funkcje gazodynamiczne. Oficyna Wydawnicza Politechniki Rzeszowskiej, Rzeszów 1987.

[3] Blair L.W., Russo C.J.: Compact diffusers for centrifugal compressors. Journal of Aircraft, 19 (1982), 46-51.

[4] Jarosz S., Kenny D.P., Vrana J.C.: Maszyna przepływowa odśrodkowa, zwłaszcza sprężarka odśrodkowa. Urząd Patentowy PRL. Opis patentowy nr 71428, 1974.

[5] Yaras M.I., Orsi P.: Measurements of the transient velocity field in a strongly curved diffusing bend with periodic inflow unsteadiness. Experiments Fluids, 36 (2003), 363-372.

[6] Vrana J.C.: Diffuser for centrifugal compressor. United States Patent No. 3333762, August 1967.

[7] Tuliszka E.: Sprężarki, dmuchawy i wentylatory. WNT, Warszawa 1976.

[8] Antas S.: Ocena wpływu wybranych metod modyfikacji maszyn wirnikowych turbinowych silników śmigłowych i śmigłowcowych na zapas statecznej pracy sprężarki. Oficyna Wydawnicza Politechniki Rzeszowskiej, Rzeszów 2006. 
[9] Reves G.B.: Design and performance of selected pipe-type diffusers. ASME Paper No. 77-GT-104, 1977.

[10] Antas S.: Dyfuzor rurkowy sprężarki promieniowej. J. Aeronautica Integra 1/2012 (11), 3-9.

[11] Antas S., Wolański P.: Obliczenia termo-gazodynamiczne lotniczych silników turbinowych. Oficyna Wydawnicza Politechniki Rzeszowskiej, Rzeszów 1989.

[12] Biełousow A.N., Musatkin N.F., Radko W.M.: Tieorija i rasczot awiacyonnych łopatocznych maszyn. Samarskij Gosudarstwiennyj Aerokosmiczeskij Institut, Samara 2003.

[13] Dzierżanowski P. i in.: Konstrukcja silników lotniczych. Wydaw. WAT, Warszawa 1972.

[14] Bennet I., Tourlidakis A., Elder R.L.: The design and analysis of pipe diffusers for centrifugal compressors. J. Power Energy, 214 (2000), 87-96.

\title{
CONTROLLED-CONTOUR DIFFUSER WITH CONTROLLED PROFILE
}

\begin{abstract}
The application of radial and axial-centrifugal compressors in turboprop, turboshaft and turbofan engines may require the construction of small diameters diffuser in order to obtain lower weight and smaller frontal area. Conventional exhaust diffusers typically have large outlet diameters for exit Mach numbers lower than 0.2 and low swirl flow to the combustor, hence the design of channel of the low-diameter diffusers called controlled-contour, fishtail-shaped diffuser or diffusing trumpet is complex. The cross-sectional shape of these channels is varied from circular to oval to elliptic and to rectangular. The paper presents an original method for determining the flow parameters in the channel and at the outlet section of the downstream diffusing trumpet for a pipe diffuser, which constitutes the downstream duct of the radial or axial-centrifugal compressor with the pipe diffuser. It also illustrates a new method for determining the geometrical parameters of the diffuser. Mentioned methods (for conceptual design of a compressor with pipe diffuser) are based on Pythagorean theorem, properties of ellipse, equation of continuity, energy equation, first law of thermodynamics, Euler's moment of momentum equation, gasodynamic functions and definitions used in theory of turbo-machines. The final part of the article includes principles of selection of the computational value pressure ratio for the compressor with the pipe diffuser.
\end{abstract}

Keywords: compressor, downstream duct, controlled-contour diffuser

DOI:10.7862/rm.2013.32

Otrzymano/received: $15.04 .2013 \mathrm{r}$.

Zaakceptowano/accepted: $12.08 .2013 \mathrm{r}$. 